\title{
Changes in hydrolytic enzyme activities of naïve Atlantic salmon Salmo salar skin mucus due to infection with the salmon louse Lepeophtheirus salmonis and cortisol implantation
}

\author{
Neil W. Ross ${ }^{1, *}$, Kara J. Firth ${ }^{1,2}$, Anping Wang ${ }^{1}$, John F. Burka ${ }^{2}$, Stewart C. Johnson ${ }^{1}$ \\ ${ }^{1}$ Institute for Marine Biosciences, National Research Council of Canada, 1411 Oxford St., Halifax, Nova Scotia B3Z 3H1, \\ Canada
}

${ }^{2}$ Department of Anatomy and Physiology, Allantic Veterinary College, University of Prince Edward Island, Charlottetown, Prince Edward Island C1A 4P3, Canada

\begin{abstract}
The changes in the activities of mucus hydrolytic enzymes and plasma cortisol levels were examined following infection of Atlantic salmon Salmo salar with the salmon louse Lepeophtheirus salmonis and these changes were compared with those resulting from elevated plasma cortisol. Salmon were infected at high (Trial $1 ; 178 \pm 67$ ) and low (Trial 2; $20 \pm 13$ ) numbers of lice per fish and the activities of proteases, alkaline phosphatase, esterase and lysozyme in the mucus, as well as plasma cortisol levels were determined. At both levels of infection, there were significant increases of protease activity over time (1-way K-WANOVA; Trial 1, $\mathrm{p}=0.004$; Trial 2, $\mathrm{p}<0.001$ ). On several sampling days, generally on later days in the infections, the mucus protease activities of infected fish were significantly higher than control fish (Student's $t$-tests; $\mathrm{p}<0.05$ ). In addition, zymography experiments demonstrated bands of proteases at 17 to $22 \mathrm{kDa}$ in the mucus of infected salmon that were absent in the mucus from non-infected fish and absent in the plasma of salmon. The intensity of these protease bands increased in the mucus over the course of both infections. However, plasma cortisol levels were elevated only in the heavily infected fish from the first trial. At high infection levels (Trial 1), alkaline phosphatase activity was higher in the mucus of infected fish at all days ( $t$-test, $p<0.05$ ). However, at the lower infection level (Trial 2), the mucus alkaline phosphatase activity did not differ significantly between infected and non-infected fish. Esterase and lysozyme activities were very low and did not change with time nor between non-infected and infected salmon in either challenge. Mucus enzyme activities of cortisolimplanted salmon did not change over time, nor were there any differences in activities between cortisol-implanted and control salmon. The present study demonstrates biochemical changes resulting from sea lice infection of Atlantic salmon occurring at the site of host-pathogen interaction, the mucus layer. However, the origin of these enzymes, whether host or pathogen, remains to be determined.
\end{abstract}

KEY WORDS: Atlantic salmon - Salmo salar Lepeophtheirus salmonis - Sea lice $\cdot$ Protease Enzyme Skin mucus · Cortisol

\section{INTRODUCTION}

Lepeophtheirus salmonis is a common marine ectoparasitic copepod of wild and pen-reared salmonids throughout the northern hemisphere (Kabata 1979, 1988, Wootten et al. 1982). When present in low abundance, $L$. salmonis does not pose a health problem to

\footnotetext{
•E-mail: neil.ross@nrc.ca
}

its hosts. However, heavy infections of L. salmonis frequently result in the death of both wild and sea-farmed salmonids (White 1940, Brandal et al. 1976, Tully 1993, Johnson et al. 1996). The lifecycle of $L$. salmonis consists of 5 phases and 10 stages. These include 2 free-swimming naupliar stages, 1 free-swimming infectious copepodid stage, 4 attached chalimus stages, 2 preadult stages, and an adult stage (Johnson \& Albright 1991). 
Although Lepeophtheirus salmonis is an economically important parasite, many aspects of its basic biology, especially the nature of the host parasite relationship, are unknown. In the laboratory, it has been demonstrated that resistance to infection with $L$. salmonis differs between species of salmon. Johnson \& Albright (1992a) demonstrated that naive coho salmon are more resistant to infection than naive chinook salmon, with naive Atlantic salmon being the least resistant species. Differences in the magnitude of the response of non-specific (innate) host defense mechanisms in the initial phases of the infection appear to account for these differences. Johnson \& Albright (1992a) showed that $L$. salmonis developed faster on naive Atlantic salmon than on naive chinook salmon and suggested that nutritional and/or non-specific host defense mechanisms were responsible for the difference. Suppression of non-specific host defense mechanisms, such as the magnitude of the inflammatory response and epithelial hyperplasia, has been shown to decrease the resistance of naïve coho salmon to infection (Johnson \& Albright 1992b) and to increase the growth rate of L. salmonis on chinook salmon (S.C.J. pers. obs.)

Fish serum and skin mucus are known to contain a number of antipathogenic substances such as lysozyme, complement, interferon, C-reactive protein, transferrin, lectins, proteases and other substances (Yano 1996). Since Lepeophtheirus salmonis feeds on host mucus, tissues and blood, these substances may be important in mediating the interaction between $L$. salmonis and its salmon hosts (Kabata 1974, Brandal et al. 1976). The objective of the present study was to investigate the effects of infection with $L$. salmonis on the serum and mucus biochemistry of naive Atlantic salmon. Exogenous cortisol administered as intraperitoneal implants was used to simulate the immunosuppressive effects of chronic stress such as occurs during disease outbreaks to determine whether observed changes in serum and mucus biochemistry were a direct result of $L$. salmonis infection or part of a larger stress response by the salmon.

\section{MATERIALS AND METHODS}

Fish maintenance, parasite exposure and examination. Atlantic salmon smolts (S1) were transferred from freshwater into seawater over a $5 \mathrm{~d}$ period in a flowthrough system. Post-smolts were maintained in $450 \mathrm{l}$ tanks supplied with ambient flow-through seawater ranging in temperature from 9 to $14^{\circ} \mathrm{C}$ and a $14 \mathrm{~h}$ light: $10 \mathrm{~h}$ dark photoperiod for at least $2 \mathrm{wk}$ prior to any challenges. Similar conditions were maintained for the sea lice challenges. Temperature of the water in the cortisol challenge varied from 9 to $17^{\circ} \mathrm{C}$. All fish used in this study were smolted and reared in sand-filtered seawater to ensure no previous exposure to Lepeophtheirus salmonis. They were fed a commercial dry pellet feed (Ewos, Surrey, BC) at approximately $1 \%$ body weight $\mathrm{d}^{-1}$.

Ovigerous Lepeophtheirus salmonis were collected from farmed Atlantic salmon from several sites in the Bay of Fundy, New Brunswick, Canada. The eggs were hatched and the larvae reared to the infectious copepodid stage in $40 \mathrm{l}$ tanks supplied with flowing sand filtered seawater at a temperature of approximately $12^{\circ} \mathrm{C}$. Circulation in the tanks was maintained by gentle aeration and copepod loss was prevented by the use of large surface area screens of $100 \mu \mathrm{m}$ Nitex mesh covering the outflows.

At sampling, fish were anaesthetized in indiviciual buckets using $250 \mathrm{mg} \mathrm{l}^{-1}$ tricaine methanesulfonate (MS-222; Syndel Laboratories, Vancouver, BC). In the infection trials each fish was placed in an individual anaesthetic bath along with the net used to capture it. Mucus and plasma samples were obtained as described below. Total lice counts for each fish were obtained from buckets, nets, bodies, fins, gills and mucus samples. Fork lengths and wet weights of all fish were determined. To compensate for differences in size among the hosts, the number of copepods was corrected to a standard wet body weight of fish $(60 \mathrm{~g})$ in each trial

In Infection Trial 1, there was 1 control and 1 infected group of 40 naïve Atlantic salmon, ranging in weight from 31.9 to $74.6 \mathrm{~g}$ (average $55.5 \mathrm{~g}$ ). Fish were exposed to high numbers of infectious copepodids (approx. 200 fish $\left.^{-1}\right)$, resulting in high copepod burdens (178 \pm 67). Seven fish from each group were sampled at 3,5 and $10 \mathrm{~d}$ post-infection (DPI).

In Infection Trial 2, there was 1 control and 1 infected group of 40 naive Atlantic salmon, ranging in weight from 30.1 to $99.4 \mathrm{~g}$ (average $56.9 \mathrm{~g}$ ). Fish were exposed to lower numbers of infectious copepodids (approx. $\left.20 \mathrm{fish}^{-1}\right)$, resulting in lower copepod burdens $(20 \pm 13)$. Six fish from each group were sampled at $0,3,5,8,12$ and 17 DPI.

In Trial 3 (cortisol administration), there were 4 experimental groups of 30 naive Atlantic salmon each, ranging in weight from 39.6 to $131.2 \mathrm{~g}$ (average $90.6 \mathrm{~g}$ ). Two groups received exogenous cortisol in vegetable shortening (Crisco All-Vegetable Shortening, Proctor \& Gamble Inc., Toronto, ON) administered as intraperitoneal (i.p.) implants, 1 group only vegetable shortening, and 1 group being anaesthetized but not injected. Six fish of each group were sampled at 0,7 , 14 and 21 DPI.

Cortisol administration. For administration of cortisol, vegetable shortening was pasteurized at $70^{\circ} \mathrm{C}$, cooled to $30^{\circ} \mathrm{C}$, and mixed with hydrocortisol (Sigma 
No. H-4001, St. Louis, MO) to yield a final concentration of $22.6 \mathrm{mg}$ hydrocortisol $\mathrm{ml}^{-1}$ shortening. Fish were anaesthetized with MS-222 (125 $\mathrm{mg} \mathrm{ml}^{-1}$ ) and injected i.p. with $0.2 \mathrm{ml}$ of cortisol solution $\mathrm{fish}^{-1}$. This resulted in an implant of approximately $50 \mu \mathrm{g}$ hydrocortisol $\mathrm{g}^{-1}$ of fish based on average fish weight of $90.6 \mathrm{~g}$. Cortisol administered at this level results in plasma cortisol levels approximately double to those seen in chronically stressed Atlantic salmon (Specker et al. 1994). The sham-injected group was anaesthetized as above and injected i.p. with $0.2 \mathrm{ml}$ of pasteurized vegetable shortening fish ${ }^{-1}$. Control fish were anaesthetized as above but received no injection.

Mucus collection. To collect mucus, fish were anaesthetized with MS-222 as above and placed in individual plastic bags containing $5 \mathrm{ml}$ of $100 \mathrm{mM}$ ammonium bicarbonate $\left(\mathrm{NH}_{4} \mathrm{HCO}_{3}\right) \mathrm{pH} 7.8$ for approximately $1 \mathrm{~min}$. When fish were removed from the bag, an additional $5 \mathrm{ml}$ of buffer were added and the bags were placed on ice. To remove copepods or other foreign material, mucus samples were transferred into sterile $15 \mathrm{ml}$ tubes, centrifuged at $2730 \times g$ and $4^{\circ} \mathrm{C}$ for $15 \mathrm{~min}$. Samples were then aliquoted and stored at $-80^{\circ} \mathrm{C}$ until use.

Plasma collection. After the mucus samples were obtained, blood samples were collected from the caudal vein into heparinized tubes and place on ice. Blood samples were spun at $500 \times g$ for $5 \mathrm{~min}$ and the resulting plasma was aliquoted into sterile cryotubes and stored at $-80^{\circ} \mathrm{C}$ until use. Cortisol levels of plasma samples were determined using a Coat-A-Count ${ }^{(i)}$ kit (Diagnostic Products Corp., Los Angeles, CA).

Protease assays. Protease activity in the mucus was examined by zymography experiments and azocasein hydrolysis assays. Protease activity in plasma of a few fish was examined by zymography. Zymography was conducted following a modification of the methods described in Hassel et al. (1996). Samples were thawed on ice and their protein concentration was determined using the dye binding method (Bradford 1976). After mixing $1: 1$ with $2 \times$ sodium dodecyl sulfate-polyacrylamide gel electrophoresis (SDS-PAGE) sample buffer (final concentrations: $2 \%$ SDS, 10\% glycerol, $62 \mathrm{mM}$ Tris-HCl, pH 6.8; Laemmli 1970), an equal amount of protein for each mucus sample ( $3 \mu \mathrm{g}$ protein) was loaded onto a $12 \%$ SDS-PAGE gel containing $0.1 \%$ gelatin. Pre-stained low range molecular weight markers (BioRad, Mississauga, ON) were loaded onto each gel. Gels were run at $4^{\circ} \mathrm{C}$ and $150 \mathrm{~V}$ for approximately 1 h. Following electrophoresis, gels were washed 3 times at $4^{\circ} \mathrm{C}$ with $2.5 \%$ Triton X-100, $50 \mathrm{mM}$ Tris- $\mathrm{HCl}$, $\mathrm{pH} 7.5$, then incubated in the same buffer containing $50 \mathrm{mM} \mathrm{MgCl}_{2}, 62.5 \mathrm{mM} \mathrm{CaCl}_{2}$, on a shaker at $30^{\circ} \mathrm{C}$ for approximately $19 \mathrm{~h}$. Gels were stained in $0.1 \%$ amido black in $\mathrm{MeOH} / \mathrm{H}_{2} \mathrm{O} / \mathrm{AcOH}(45: 45: 10)$ for $1 \mathrm{~h}$ and destained with $\mathrm{MeOH} / \mathrm{H}_{2} \mathrm{O} / \mathrm{AcOH}$ (50:48:2).
For the azocasein hydrolysis assay (Charney \& Tomarelli 1947), samples were added to azocasein (Sigma, St. Louis, $\mathrm{MO}_{3} 3.5 \mathrm{mg} \mathrm{ml}^{-1}$ dissolved in $100 \mathrm{NH}_{4} \mathrm{HCO}_{3}$. $\mathrm{pH} \mathrm{7.8)}$ and tubes were placed on a shaker at $30^{\circ} \mathrm{C}$ for approximately $19 \mathrm{~h}$. The reaction was stopped by adding trichloroacetic acid $(4.5 \%$ final concentration), the samples were cooled on ice, centrifuged at $15000 \times g$ for $5 \mathrm{~min}$ and $100 \mu \mathrm{l}$ of each supernatant was added to $100 \mu \mathrm{l}$ of $0.5 \mathrm{M} \mathrm{NaOH}$ in microplate wells. Optical density (OD) was measured at $450 \mathrm{~nm}$ on a Thermomax microplate reader (Molecular Devices, Sunnyvale, CA).

Alkaline phosphatase, esterase and lysozyme assays. For alkaline phosphatase (E.C. 3.1.3.1) assays, mucus samples were incubated with $4 \mathrm{mM} p$-nitrophenyl phosphate (Sigma, St. Louis, MO) in $100 \mathrm{mM}$ ammonium bicarbonate buffer with $1 \mathrm{mM} \mathrm{MgCl}_{2}, \mathrm{pH} 7.8$ at $30^{\circ} \mathrm{C}$. The increase in OD was measured continuously over 2 to $3 \mathrm{~h}$ at $405 \mathrm{~nm}$ using a microplate reader. The initial rate of the reaction was used to calculate the activity. One unit (U) of activity was defined as the amount of enzyme required to release $1 \mu \mathrm{mol}$ of $p$-nitrophenol product in $1 \mathrm{~min}$. The extinction coefficient of $p$-nitrophenol in the microplate wells was experimentally determined

Esterase (E.C. 3.1.1.1) activity was determined continuously over $3 \mathrm{~h}$ at $30^{\circ} \mathrm{C}$ and $405 \mathrm{~nm}$ using $0.4 \mathrm{mM}$ p-nitrophenyl myristate (Sigma, St. Louis, $\mathrm{MO}$ ) as substrate in $100 \mathrm{mM}$ ammonium bicarbonate, $0.5 \%$ Triton $\mathrm{X}-100, \mathrm{pH} 7.8$. The activity was determined as for alkaline phosphatase.

A turbidimetric assay (Shugar 1952) for lysozyme (E.C. 3.2.1.17) was adapted for continuous monitoring of absorbance in a microplate reader. Mucus samples were lyophilized, resuspended in an equal volume of $40 \mathrm{mM}$ sodium phosphate buffer prior to assay and incubated with lyophilized cells of Micrococcus lysodeikticus (Sigma, St. Louis, $\mathrm{MO} ; 0.3 \mathrm{mg} \mathrm{ml}^{-1}$ ) at $30^{\circ} \mathrm{C}$ for $1 \mathrm{~h}$. The initial rate of the reaction was used to calculate the activity, with $1 \mathrm{U}$ of activity being defined as the amount of enzyme that catalyzed a decrease in absorbance at $450 \mathrm{~nm}$ of $0.001 \mathrm{~min}^{-1}$.

Statistical analyses. Intensity data were $\log (x+1)$ transformed when necessary and differences in copepod intensity between sampling days were investigated by Student's t-tests. Enzyme data were log or square root transformed when necessary and differences in activity between treatments were investigated by analysis of variance (ANOVA) procedures. Multiple comparisons of enzyme activity over time and between treatments at each sampling period were made using Tukey or t-tests. When the data could not be normalized, the data were ranked and Kruskal-Wallis 1-way ANOVA on ranks (K-WANOVA) and Dunn's multiple comparison procedure were performed. 


\section{RESULTS}

\section{Infection trials}

Intensity of infection

The intensity of Lepeophtheirus salmonis on naive Atlantic salmon over time for both infection trials is presented in Fig. 1. In Infection Trial 1, the infection level was very high $(178 \pm 67)$ and there was no significant difference in the number of lice on different sampling days $(p<0.05)$. Within a $12 \mathrm{~h}$ period at $12 \mathrm{DPI}$ the remaining fish in Trial 1 had died or become moribund. This mortality event corresponded with the molting of the lice to the pre-adult stage. In Infection Trial 2 the level of infection was considerably lower $(20 \pm 13)$ and there were significantly fewer copepods at $3 \mathrm{DPI}$ than at 12 and 17 DPI, and at 5 and 8 DPI compared to 12 DPI (Student's t-test; $\mathrm{p}<0.05$ ).

\section{Plasma cortisol}

There were no significant differences in the plasma cortisol levels for either treatment in either trial over time (Fig. 2). In Infection Trial 1, there were significantly higher levels of plasma cortisol in the infected group when compared to the controls on Days 3 and 10 ( $t$-tests; $p \leq 0.05)$. In Infection Trial 2 , there was no significant difference in the cortisol levels between control and infected salmon on any sampling day.

\section{Mucus enzymes}

Total protease activity in the mucus of control and infected Atlantic salmon for both infection trials is presented in Fig. 3. In both infection trials there was a sig-

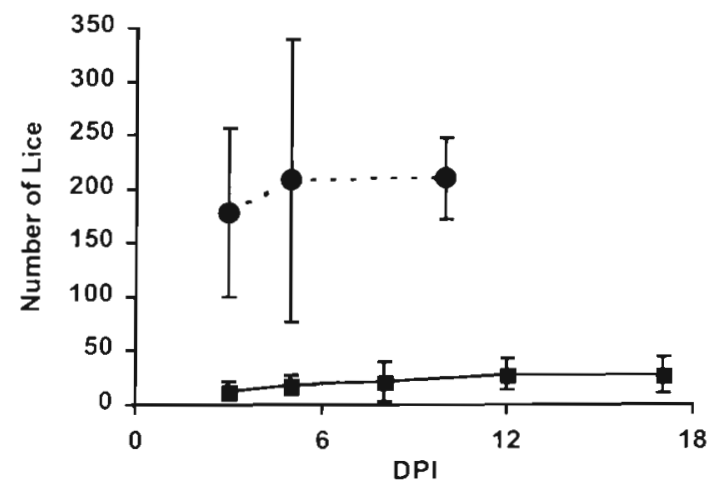

Fig. 1. Mean (+SE) intensity of Lepeophtheirus salmonis on naïve Atlantic salmon at various days post-infection (DPI) corrected to a standard wet body weight of fish $(60 \mathrm{~g})$. Salmon were maintained at approximately $12^{\circ} \mathrm{C}$ and ambient salinity (29 to $31 \mathrm{ppt}$ ).
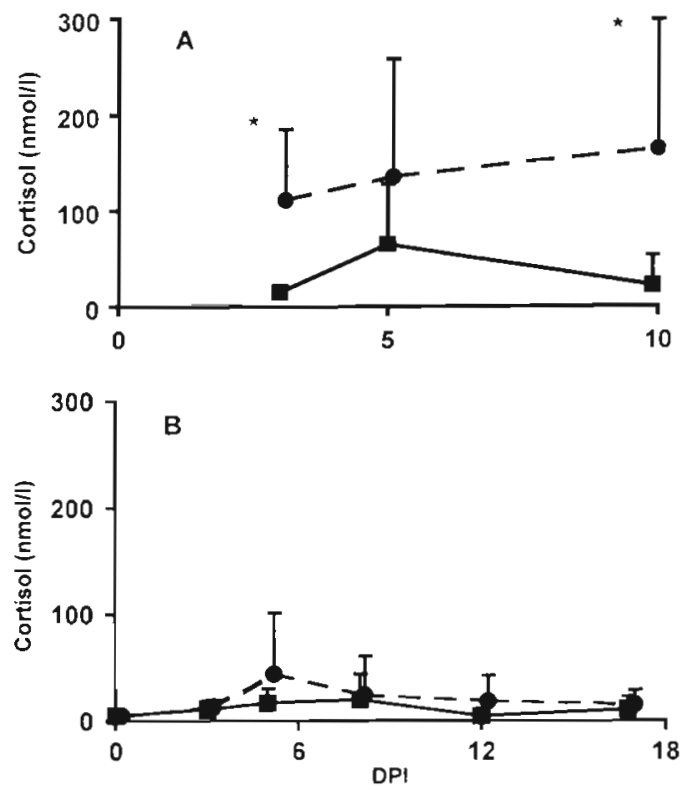

Fig. 2. Plasma cortisol levels ( $\mathrm{nmol} \mathrm{l}^{-1}$ ) in naive Atlantic salmon infected with high (Trial 1) and lower (Trial 2) numbers of Lepeophtheirus salmonis at various days post-infection (DPI).

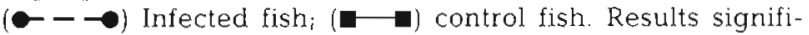
cantly different $(\mathrm{p} \leq 0.05)$ from control are indicated by an asterisk (*). (A) Infection Trial 1; (B) Infection Trial 2
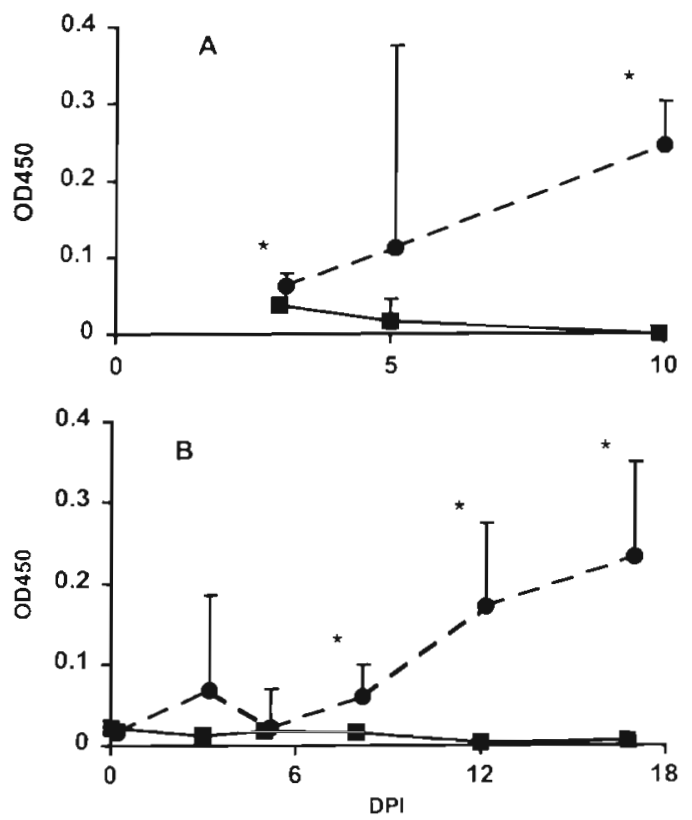

Fig. 3. Mean ( $+\mathrm{SD}$ ) protease activity in the mucus of noninfected control and infected naïve Atlantic salmon at various days post-infection (DPI) with Lepeophtheirus salmonis. Protease activity was determined by Azocasein hydrolysis at $30^{\circ} \mathrm{C}$ and is presented as total colour produced in $19 \mathrm{~h}$. $(\bullet-\rightarrow)$ Infected fish; (-) control fish. Results significantly different $(p \leq 0.05)$ from control are indicated by an asterisk (*). (A) Infection Trial $1_{i}$ (B) Infection Trial 2. OD: optical density 
nificant increase in total protease activity in the mucus of infected salmon over time (1-way K-WANOVA, Infection Trial $1[\mathrm{p}=0.004]_{\text {; }}$ Infection Trial $2[\mathrm{p}<$ $0.001]$ ). In Infection Trial 1 there was a significant decrease in the mucus protease activity of control fish over time (1-way K-WANOVA, Infection Trial 1 [p $=$ $0.001])$. In Infection Trials 1 and 2, there was significantly higher protease activity in the mucus of infected fish at 3 and 10 DPI (Trial 1) and at 8, 12 and 17 DPI (Trial 2) ( $t$-tests; $\mathrm{p}<0.05$ ).

Zymograms of mucus samples from non-infected and infected salmon demonstrated a general increase in mucus protease activity over time in both infection trials (Fig. 4). This included the appearance of a series of low molecular weight bands (17 to $22 \mathrm{kDa}$ ) which were present in infected fish in both infection trials as early as 3 DPI. The intensity and number of these bands generally increased over time. Low molecular weight protease bands were not observed in zymo- grams of plasma samples of non-infected or infected fish (Day 5, Trial 1, data not shown). As there were no differences in the plasma protease profiles between infected and non-infected fish in this experiment, no further experiments on plasma protease activity were conducted.

In Infection Trial 1 alkaline phosphatase activities were significantly higher in mucus of infected fish when compared to controls on all days ( $t$-test; $p \leq 0.05$ ) (Fig. 5). There were no significant differences in alkaline phosphatase activities over time for control and infected fish in either trial and there was no significant difference between the control and infected fish in Trial 2.

Esterase and lysozyme activities in the mucus of both non-infected and infected salmon were very low being near or at the limit of detection of our assays (data not shown). There were no trends in activities over time nor between the control and infected groups.


Fig. 4. Zymograms of protease activity in the mucus of individual non-infected control and infected naive Atlantic salmon at various times post-infection with Lepeophtheirus salmonis. Numbers at top of each gel identify the individual fish from which the mucus originated, with $3 \mu \mathrm{g}$ of mucus protein being added to each lane. Arrows indicate series of low molecular weight (17 to $22 \mathrm{kDa}$ ) bands observed only in infected fish. (A) Infection Trial 1; (B) Infection Trial 2. Molecular weights of markers are shown on left 

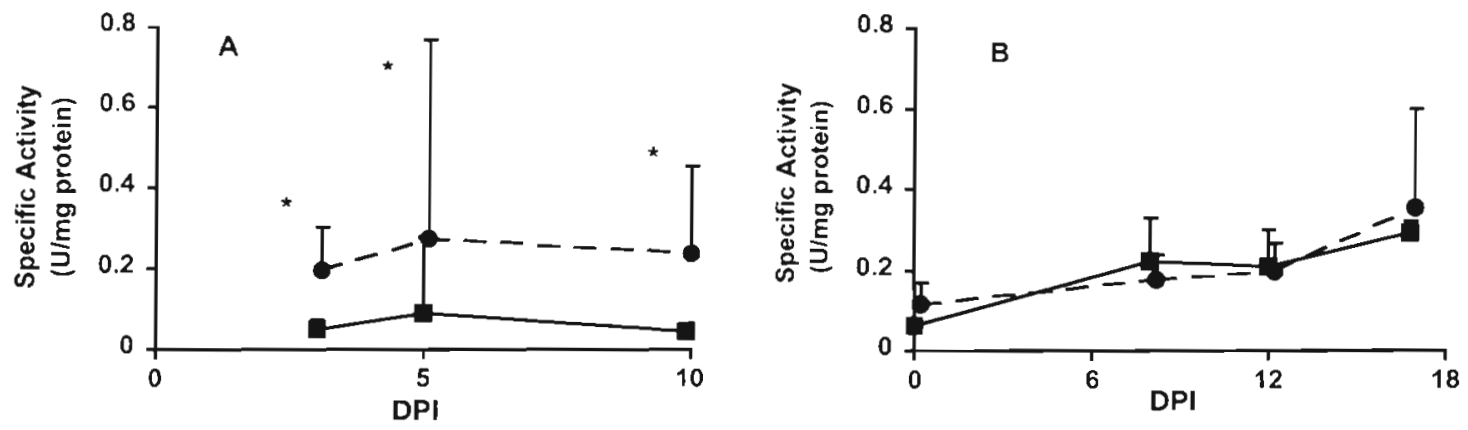

Fig. 5. Mean ( $+\mathrm{SD})$ specific activity of alkaline phosphatase in the mucus of non-infected control and infected naive Atlantic salmon at various days post-infection (DPI) with Lepeophtheirus salmonis. Alkaline phosphatase activity was determined as described in 'Materials and methods'. (- - $\rightarrow$ ) Infected fish; (- - control fish. Results significantly different (p $\leq 0.05)$ from control are indicated by an asterisk (*). (A) Infection Trial $1_{i}(B)$ Infection Trial 2

\section{Cortisol challenge}

Intraperitoneal implantation of hydrocortisol resulted in significantly higher levels of serum cortisol than seen in the non-injected and oil-injected control groups on all days sampled post-implantation (Fig. 6A) (Kruskal-Wallis 1 -way ANOVA, $\mathrm{p} \leq 0.05$ ). There was no significant difference between any of the groups before cortisol implantation or between the 2 control groups post-implantation.
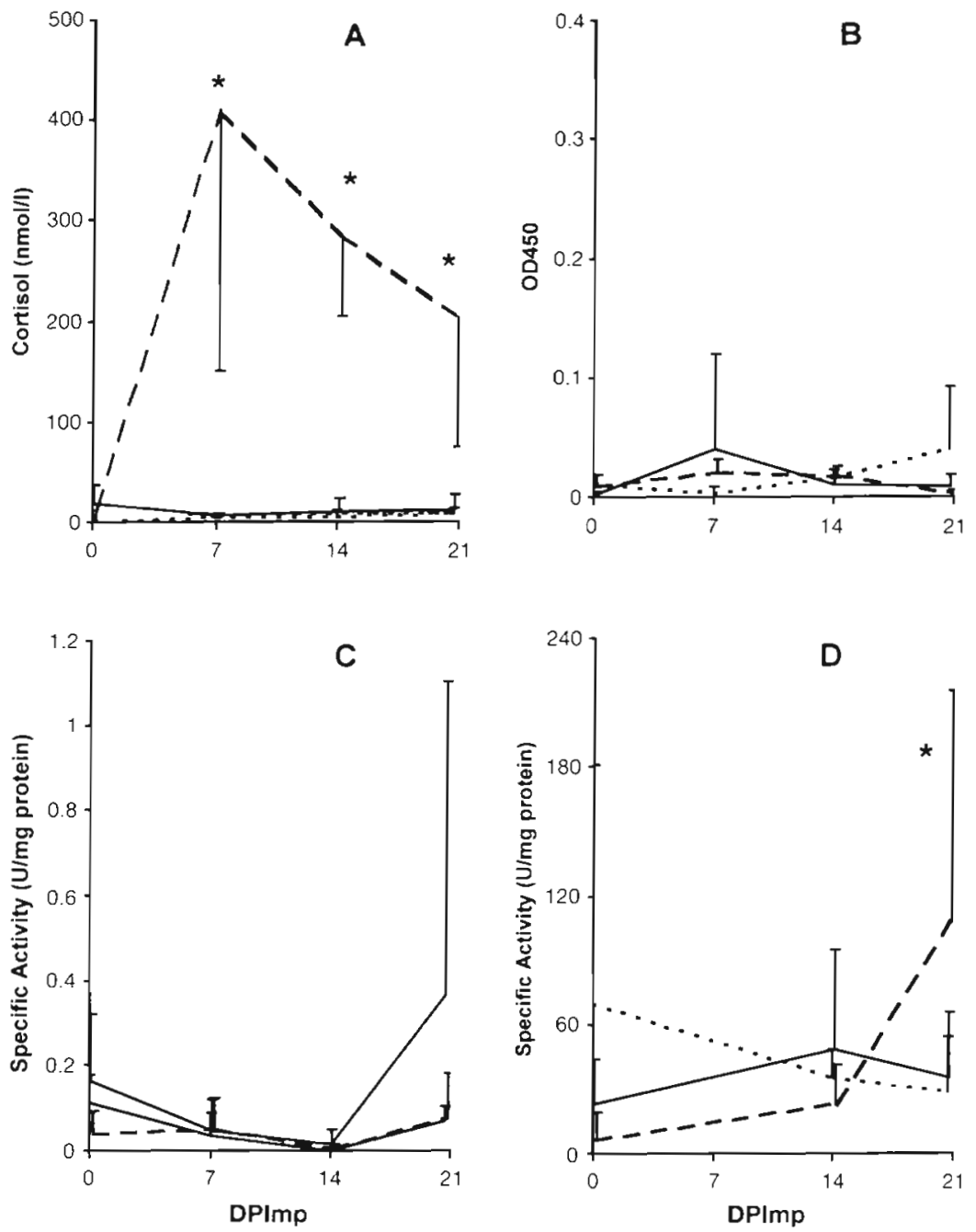

Fig. 6. Mean $(+\mathrm{SD})$ of $(A)$ plasma cortisol concentration ( $\mathrm{nmol} \mathrm{l}^{-1}$ ), (B) protease activity $\left(\mathrm{OD}_{450}\right),(\mathrm{C})$ alkaline phosphatase and (D) lysozyme specific activities (U $\mathrm{mg}^{-1}$ protein) in the mucus of non-injected control $(-\cdots)$, oil-injected control (-) and cortisol implanted (- - - ) Atlantic salmon at various days postimplantation (DPImp) with hydrocortisol. Results significantly different $(p \leq 0.05$ ) from the control groups are indicated by an asterisk $(*)$ 
Implantation with cortisol had no significant effect on protease, alkaline phosphatase, lysozyme or esterase activities in the mucus (Fig, 6B,C,D). In general, the levels of these enzymes were similar to those seen in the control fish in Infection Trials 1 and 2. In the mucus of cortisol-implanted salmon, there was no evidence of the low molecular weight proteases that were observed in the mucus of lice infected fish (data not shown).

\section{DISCUSSION}

In the present study naïve Atlantic salmon were infected with high $(178 \pm 67)$ and low $(20 \pm 13)$ numbers of Lepeophtheirus salmonis. With respect to copepod abundance, the results of these infections were consistent with other studies (Bjrørn \& Finstad 1997, Bowers et al. 2000). As observed previously by Grimnes \& Jakobsen (1996), the high level of sea lice infection in Trial 1 of the present study resulted in mass mortality of infected salmon within a $24 \mathrm{~h}$ period following the molt of the sea lice to the pre-adult stage. Heavy infestation of sea trout post-smolts also resulted in mortalities as the lice reached the pre-adult stage (Bjørn \& Finstad 1997). The lower numbers of lice found in the early days of infection in Trial 2 relative to later days is most likely due to loss of copepodids during sampling because the copepodid stage is mobile and not attached to the fish surface (Johnson \& Albright 1992a).

This study examined changes in several hydrolytic enzymes in naïve Atlantic salmon skin mucus in response to infection with the ectoparasite Lepeophtheirus salmonis. Fish mucus has been reported to contain a variety of substances that are thought to be important for protection against pathogen invasion, including hydrolytic enzymes (Ingram 1980, Ellis 1981, Fletcher 1982, Yano 1996). In previous studies of mucus enzymes, some researchers have waited several hours after death to remove the mucus (Hjelmeland et al. 1983) or have scraped it from the fish surface (Hutchinson et al. 1996, Buchmann \& Bresciana 1998). However, these methods may result in the release and activation of substances from the epithelial cells and or from the peripheral circulation. Aranishi \& Nakane (1997) found that scraping the epidermis with a spatula yielded much higher protease activity than wiping the mucus off with a glove. In the present study mucus was collected by gently rinsing the fish in ammonium bicarbonate buffer. We suggest that the method of mucus collection used in the present study yielded samples which accurately represented what was naturally present in the fish skin mucus at the time of sampling.

In this study, both low and high levels of infection with Lepeophtheirus salmonis resulted in elevated levels of proteases in the mucus, including the appear- ance of low molecular weight proteases between 17 and $22 \mathrm{kDa}$. These low molecular weight proteases were not observed in mucus sampled from non-infected salmon or in the plasma of either infected or noninfected fish, suggesting that the proteases were not derived from leakage of salmon plasma to the skin surface. Trypsin has previously been purified from the skin mucus of rainbow trout (Hjelmeland et al. 1983) and identified immunohistochemically in mucussecreting cells (Braun et al. 1990). The low molecular weight proteases observed in infected fish in this study have similar molecular weights as trypsin

It is possible that salmon release proteases into the skin as a defense mechanism against invading lice. Proteases could act directly on the pathogen or prevent invasion indirectly by modifying mucus consistency that results in increased sloughing of mucus and pathogen removal from the body surfaces (Aranishi et al. 1998). Alternatively, proteases may be released during tissue damage caused by Lepeophtheirus salmonis feeding. Other arthropod parasites such as the cattle tick Boophilus microplus, the mosquito Aedes aegypti, the sheep blowfly Lucilia cuprina and the buffalo fly Haematobia irritans exigua are known to have proteases and other enzymes in their saliva which are thought to aid in their establishment and feeding on the host (Kerlin \& Hughes 1992, Casu et al. 1996). L. salmonis is known to feed on host mucus, skin and blood (Brandal et al. 1976) and to have trypsin-like proteases present within its gut (Jenkins et al. 1993 Roper et al. 1995). It is unknown whether this species produces saliva to aid in the passage of this material across the relatively long distance of the oral cone and oesophagus. Alternatively, this species might, as suggested for Lucilia cuprina, regurgitate stomach contents or excrete this material on to the surface of the host to aid in its feeding activities (Casu et al. 1996)

Protease activity was at very low or non-detectable levels in mucus from control fish in both experiments when azocasein was used as the substrate. These findings are inconsistent with the results of the zymography experiments, which used gelatin as the substrate and which clearly showed several protease bands. This discrepancy may be accounted for by either a difference in activity of the proteases towards azocasein and gelatin (i.e. higher activity against gelatin), or that these proteases exist in the mucus as non-activated pro-enzymes and are activated during SDS-PAGE procedures. The denaturation and renaturation of proteases during zymography has been shown to activate latent metalloproteinases (Kleiner \& Stetler-Stevenson 1994, Makowski \& Ramsby 1996).

The lack of a relationship between plasma cortisol and protease activity in the mucus in either infection trial and in the cortisol implantation trial suggests that 
chronically elevated cortisol levels, such as are seen in situations of chronic stress and disease, are not associated with the observed increase in protease activity in the mucus of diseased fish.

In Trial 1, with the high number of lice per fish, alkaline phosphatase activity in the mucus of infected fish was higher than that of the controls. There was no significant difference in alkaline phosphatase level between infected and control fish at the lower infection level or between cortisol-implanted and control fish. The cause of this increase in alkaline phosphatase activity in the mucus is unknown but may be related to high levels of stress due to the high number of lice on the fish. Iger \& Abraham (1997) reported that a number of stressors including acidity, thermal elevation, polluted water and distilled water, caused increases in the number of alkaline phosphatase-positive Rodlet cells in the skin of rainbow trout. However, cortisol implantation did not elicit a similar increase. These results were consistent with the observations reported in this study. In another study, changes in the levels of tissue and blood alkaline phosphatase isoenzymes were associated with smolting and gonadal development (Johnston et al. 1994). However, alkaline phosphatase isoenzymes in skin and mucus were not examined.

The increased alkaline phosphatase activity seen at the high level of infection could also be derived from secretions or excretions of Lepeophtheirus salmonis. In Trial 2, there may have been too few lice on the fish to produce sufficient alkaline phosphatase or trigger release of enough enzyme from salmon skin to be detectable in our assay. Phosphatase activity has been detected in the saliva of other arthropod parasites (Kerlin \& Hughes 1992).

Throughout both the infection and the cortisolimplantation trials, esterase and lysozyme activity in the mucus of both non-infected and infected fish was at or below the level of detection of our assays. Esterase activity has been previously identified in arthropod saliva (Kerlin \& Hughes 1992). It is possible that our assay techniques for these enzymes were not sensitive enough to detect Lepeophtheirus salmonis derived secretions or excretion of these enzymes in the mucus. Lysozyme levels in blood have been shown to increase following acute stress (Wedermeyer \& McLeay 1981 , Demers \& Bayne 1997, Fevolden et al. 1999) yet were reduced by chronic stress (Moeck \& Peters 1990, Yin et al. 1995). Blood lysozyme levels were not monitored in the present study.

In this study we have identified increased proteolytic and alkaline phosphatase activities in the mucus of naive Atlantic salmon infected with the salmon louse Lepeophtheirus salmonis. We are presently determining the source of these enzymes and the roles that these enzymes play in the host parasite relationship.
Acknowledgements. The authors would like to thank Scott MacIntosh and Maedi Bartolacci for assistance with enzyme assays. This work was supported by NRC, a grant from the NSERC/NRC Partnershup Program and the Canadian Salmon Health Consortium. NRCC \# 42322 .

\section{LITERATURE CITED}

Aranishi F, Nakane M (1997) Epidermal proteases of the Japanese eel. Fish Physiol Biochem 16:471-478

Aranishi F, Mano N, Nakane M, Hirose H (1998) Epidermal response of the Japanese eel to environmental stress. Fish Physiol Biochem 19:197-203

Bjørn PA, Finstad B (1997) The physiological effects of salmon lice infection on sea trout post smolts. Nord J Freshw Res 73:60-72

Bowers JM, Mustafa A, Speare DJ, Conboy GA, Brimblecombe M, Sims DE, Burka JF (2000) The physiological response of Atlantic salmon (Salmo salar L.) to a single experimental challenge with sea lice (Lepeophtheirus salmonis). J Fish Dis (in press)

Bradford MM (1976) A rapid and sensitive method for the quantification of microgram quantities of proteins using the principle of protein-dye binding. Anal Biochem 72: $248-254$

Brandal PO, Egidius E, Romslo I (1976) Host blood: a major food component for the parasitic copepod Lepeophtheirus salmonis Kröyeri, 1838 (Crustacea: Caligidae). Norw J Zool 24:341-343

Braun $R$, Arnesen JA, Rinne A, Hjelmeland K (1990) Immunohistochemical localization of trypsin in mucus-secreting cell layers of Atlantic salmon, Salmo salar, L. J Fish Dis 13: $233-238$

Buchmann K, Bresciani J (1998) Microenvironment of Gyrodactylus derjavini on rainbow trout Oncorhynchus mykiss: association between mucous cell density in skin and site selection. Parasitol Res 84:17-24

Casu RE, Eisemann CH, Vuocolo T, Tellam RL (1996) The major excretory/secretory protease from Lucilia cuprina larvae is also a gut digestive protease. Int J Parasitol 26: $623-628$

Charney J, Tomarelli RM (1947) A colorimetric method for the determination of the proteolytic activity of duodenal juice. J Biol Chem 171:501-505

Demers NE, Bayne CJ (1997) The immediate effects of stress on hormones and plasma lysozyme in rainbow trout. Dev Comp Immunol 21:363-373

Ellis AE (1981) Non-specific defense mechanisms in fish and their role in disease processes. Dev Biol Stand 49:337-352

Fevolden SE, Røed KH, Fjalstad KT, Stien J (1999) Poststress levels of lysozyme and cortisol in adult rainbow trout: heritabilities and genetic correlations. J Fish Biol 54:900-910

Fletcher (1982) Non-specific defence mechanisms of fish. Dev Comp Immunol Suppl 2:123-132

Grimnes A, Jakobsen PJ (1996) The physiological effects of salmon lice infection on post-smolt of Atlantic salmon. J Fish Biol 48:1179-1194

Hassel M, Klenk G, Frohme M (1996) Prevention of unwanted proteolysis during extraction of proteins from proteaserich tissue. Anal Biochem 242:274-275

Hjelmeland K, Christie M, Raa J (1983) Skin mucus protease from rainbow trout, Salmo gairdneri Richardson, and its biological significance. J Fish Biol 23:13-22

Hutchinson AJ, Ryan R, Whelan K, MacEvilly U (1996) Electrophoretic analysis of rainbow trout (Oncorhynchus mykiss) mucus. Biochem Soc Trans 24:86S 
Iger Y, Abraham M (1997) Rodlet cells in the epidermis of fish exposed to stressors. Tissue Cell 29:431-438

Ingram GA (1980) Substances involved in the natural resistance of fish to infection-a review. J Fish Biol 16:23-60

Jenkins PG, Grayson TH, Hone JV, Wrathmell AB, Gilpin ML, Harris JE, Munn CB (1993) The extraction and analysis of potential candidate vaccine antigens from the salmon louse Lepeophtheirus salmonis (Kroyer, 1837). In: Boxshall GA, Defarge D (eds) Pathogens of wild and farmed fish: sea lice. Ellis Horwood, Chichester, p 311-322

Johnson SC, Albright LJ (1991) Development, growth, and survival of Lepeophtheirus salmonis (Copepoda: Caligidae) under laboratory conditions. J Mar Biol Assoc UK 71 : 425-436

Johnson SC, Albright LJ (1992a) Comparative susceptibility and histopathology of the host response of naive Atlantic, chinook and coho salmon to experimental infection with Lepeophtheirus salmonis (Copepoda: Caligidae). Dis Aquat Org 14:179-193

Johnson SC, Albright LJ (1992b) Effects of cortisol implants on the susceptibility and the histopathology of the responses of naive coho salmon Oncorhynchus kisutch to experimental infection with Lepeophtheirus salmonis (Copepoda: Caligidae). Dis Aquat Org 14:195-205

Johnson SC, Blaylock RB, Elphick J, Hyatt KD (1996) Disease induced by the sea louse (Lepeophtheirus salmonis) (Copepoda: Caligidae) in wild sockeye salmon (Oncorhynchus nerka) stocks of Alberni Inlet, British Columbia. Can J Fish Aquat Sci 53:2888-2897

Johnston CE, Horney BS, Deluca S, Mackenzie A, Eales JG, Angus R (1994) Changes in alkaline phosphatase isoenzyme activity in tissues and plasma of Atlantic salmon (Salmo salar) before and during smoltification and gonadal maturation. Fish Physiol Biochem 12:485-497

Kabata Z (1974) Mouth and mode of feeding of Caligidae (Copepoda), parasites of fishes as determined by light and scanning electron microscopy. J Fish Res Board Can 31: $1583-1588$

Kabata Z (1979) Parasitic Copepoda of British fishes. The Ray Society, London

Kabata Z (1988) Copepoda and Branchuria. In: Margolis L, Kabata $Z$ (eds) Guide to the parasites of fishes of Canada. Part II-Crustacea. Can Spec Pub Fish Aquat Sci 101 $3-127$

Kerlin RL, Hughes S (1992) Enzymes in saliva from four parasitic arthropods. Med Vet Entomol 6:121-126

Editorial responsibility: Wolfgang Körting,

Hannover, Germany
Kleiner DE, Stetler-Stevenson WG (1994) Quantitative zymography: detection of quantities of gelatinases. Anal Biochem 218:325-329

Laemmli UK (1970) Cleavage of structural protein during the assembly of the head of bacteriophage T4. Nature 227 : $680-685$

Makowski GS, Ramsby ML (1996) Calibrating gelatin zymograms with gelatinase standards. Anal Biochem 236: 353-356

Moeck A, Peters G (1990) Lysozyme activity in rainbow trout, Oncorhynchus mykiss (Walbaum), stressed by handling, transport and water pollution. J Fish Biol 37 873-885

Roper J, Grayson TH, Jenkins PG, Hone JV, Wrathmell AB, Russell PM, Harris JE (1995) The immunocytochemical localisation of potential candidate vaccine antigens from the salmon louse Lepeophtheirus salmonis (Kroyer, 1837). Aquaculture 132:221-232

Shugar D (1952) The measurement of lysozyme activity and the ultra-violet inactivation of lysozyme. Biochim Biophys Acta 8:302-309

Specker JL, Portesi DM, Cornell SC, Veillette PA (1994) Methodology for implanting cortisol in Atlantic salmon and effects of chronically elevated cortisol on osmoregulatory physiology. Aquaculture 121:181-193

Tully O (1993) The succession of generations and growth of the caligid copepods Caligus elongatus and Lepeophtheirus salmonis parasitising farmed Atlantic salmon smolts (Salmo salar L.). J Mar Biol Assoc UK 69:279-287

Wedermeyer GA, McLea DL (1981) Methods for determining the tolerance of fishes to environmental stressors. In: Pickering AD (ed) Stress and fish. Academic Press, London, p $247-276$

White HC (1940) 'Sea lice' (Lepeophtheirus) and death of salmon. J Fish Res Board Can 5:172-175

Wootten R, Smith JW, Needham EA (1982) Aspects of the biology of the parasitic copepods Lepeophtheirus salmonis and Caligus elongatus on farmed salmonids, and their treatment. Proc R Soc Edinb (B) 81:185-197

Yano $T$ (1996) The non-specific immune system: humoral defense. In: Iwama G, Nakanishi T (eds) The fish immune system: organism, pathogen, and environment. Fish Physiol 15:105-157

Yin Z, Lam TJ, Sin YM (1995) The effects of crowding stress on the non-specific immune response in fancy carp (Cyprinus carpio L.). Fish Shellfish Immunol 5:519-529

Submitted: August 9, 1999; Accepted: January 24, 2000

Proofs received from author(s): April 28, 2000 